\title{
Immunopathology of Adipose Tissue during Metabolic Syndrome
}

\author{
Magar GHAZARIAN ${ }^{*}, 1,2$, Helen LUCK ${ }^{*}, 1,2$, Xavier S. REVELO ${ }^{2}$, Shawn WINER ${ }^{2}$, Daniel A. WINER ${ }^{1,2,3,4}$ \\ "Magar Ghazarian and Helen Luck are co-first authors in this manuscript.'Department of Immunology, University of Toronto, ON, CANADA \\ ${ }^{2}$ Division of Cellular \& Molecular Biology, Diabetes Research Group, Toronto General Research Institute (TGRI), University Health Network, Toronto, ON, CANADA \\ ${ }^{3}$ Department of Pathology, University Health Network, Toronto, ON, CANADA \\ ${ }^{4}$ Departments of Laboratory Medicine and Pathobiology, and Endocrinology, University of Toronto, Toronto, ON, CANADA
}

\begin{abstract}
Excess energy intake and a sedentary lifestyle have led to increasing incidence of obesity which is a major risk factor for the development of insulin resistance. Research in the last two decades has revealed that chronic-low grade inflammation in adipose tissue is a key link between obesity and insulin resistance. As a result, adipose tissue is now considered an active immune organ with a key role in metabolic homeostasis. In the course of obesity, cells of the immune system infiltrate visceral adipose tissue (VAT) in an active process that promotes local and systemic inflammation. This inflammatory process in VAT is driven by various subsets of immune cells and is a central mechanism connecting obesity with its metabolic complications. One key event of adipose tissue inflammation is the switching of macrophages towards a pro-inflammatory phenotype. In addition, recent research has discovered an expanding list of immune cells contributing to this inflammatory process. Pro-inflammatory immune cells are crucial to obese VAT inflammation because of their production of cytokines, which can interfere with insulin signaling in peripheral tissues. This review summarizes our current knowledge of the pathology of innate and adaptive immune cells in obese adipose tissue, with emphasis in the immunological mechanisms mediating obesity-associated insulin resistance.
\end{abstract}

Key Words: Obesity, Visceral adipose tissue, Inflammation, Immunology, Diabetes mellitus

\section{INTRODUCTION}

Obesity and type 2 diabetes (T2D) are growing epidemic concerns with the rates of obesity having more than doubled between 1980 and 2014 (1). The World Health Organization (WHO), estimates that $39 \%$ of adults worldwide are overweight and over half a billion are obese (1). It has been estimated that diabetes will become the $7^{\text {th }}$ leading cause of death by 2030 (2). In addition to T2D, obesity and metabolic syndrome are highly associated with other comorbidities such as cardiovascular disease, non-alcoholic fatty liver disease, and cancer (3-6). Over the last decade, researchers have turned to the adipose tissue as a key modulator of obesity and T2D. In addition to its function as a major energy storage depot, adipose tissue is a critical organ for metabolic and thermoregulatory processes. Obesity-related insulin resistance (IR) precedes T2D and is largely linked to chronic low-grade inflammation and altered immunity in the visceral adipose tissue (VAT) in both mice and humans. Here we discuss highlights of the immunopathological processes, both innate and adaptive, in adipose tissue inflammation during obesity-related IR.

(Turk Patoloji Derg 2015, 31(Suppl):172-180)

Received : 29.05.2015 Accepted : 01.06.2015

\section{COMPONENTS AND REMODELING OF VAT DURING OBESITY}

White adipose tissue can be divided into two major stores: subcutaneous and visceral. Subcutaneous fat is located in the hypodermis beneath the skin, whereas visceral fat connects inner organs and accumulates within the abdominal cavity and mediastinum (7). VAT is supported by a loose connective tissue that is predominately populated with tightly packed adipocytes that are vascularized by a dense network of capillaries. A second component of VAT, which excludes adipocytes, is termed the stromal vascular fraction, and includes pre-adipocytes, multi-potent stem cells, fibroblasts, vascular endothelial cells, and immune cells surrounded by the extracellular matrix (ECM). The ECM contains a variety of structural proteins and collagen networks that anchor adipocytes to maintain the structural and functional integrity of the tissue (8).

During obesity, excessive nutrient intake results in an expansion of VAT that alters both adipocyte and stromal vascular compartments (9). Although the number of adipocytes and their turnover rates seem to be consistent between lean and obese states, accumulation of triglycerides causes adipocytes to become hypertrophic (10). This growth

Correspondence: Daniel A. WINER

MaRS Centre 10-352, Toronto Medical Discovery Tower, 101 College St, Toronto ON M5G1L7, CANADA

E-mail: Dan.Winer@uhn.ca. Phone: +1 4163403190 
in cell size has been associated with increased adipokine and pro-inflammatory cytokine production that are linked to IR (11). Hypertrophic adipocytes are supported by the formation of new vascular networks, or angiogenesis, which can be a source for new therapeutic targets (12, 13). Progressive hypertrophy is accompanied by hypoxia, which likely induces adipocyte cell death via apoptosis or pyroptosis $(14,15)$. Obese adipose tissue also undergoes fibrotic changes and enhanced expression of different ECM components that can impact adiposity and glucose homeostasis $(8,16,17)$. For instance, obese VAT displays increased expression of collagen VI that is associated with greater metabolic risk in humans (16). It is believed that progressive fibrosis in VAT may also limit the amount of fat stored in adipocytes, which promotes the deposition of ectopic fat in the liver and muscle (18). Local inflammation of the growing adipose tissue is believed to drive the remodeling process (19), as well as contribute to underlying IR. Below, we discuss the roles of distinct immune cells in governing inflammation in VAT.

\section{INNATE IMMUNE CELLS}

\section{Macrophages}

Macrophages are innate immune cells that clear invading foreign pathogens and dying cells via phagocytosis. Dietinduced obese inflammation in adipose tissue is largely mediated by macrophages (20). Early on in obesity, macrophages accumulate in VAT as a result of chemokines and cytokines released by adipocytes and other immune

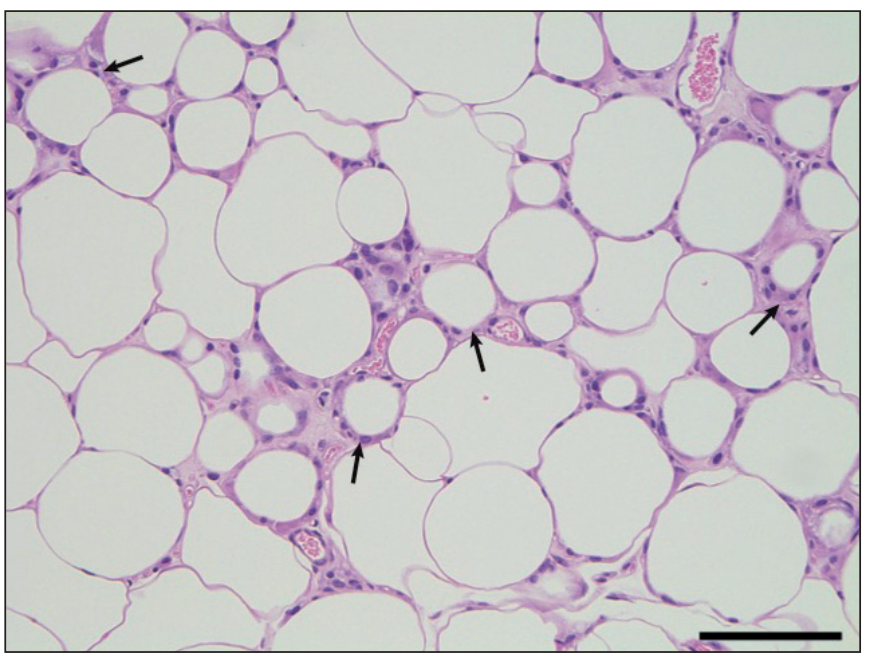

Figure 1: Obese visceral adipose tissue (VAT) exhibits increased accumulation of immune cells that localize around dying adipocytes forming crown like structures (CLS). Histological stain of VAT extracted from C57BL/6 mice fed a high fat diet (HFD) for 12 weeks and stained with hematoxylin and eosin. Arrows indicate representative CLS. Scale bar is set at $100 \mu \mathrm{m}$. cells $(21,22)$. Approximately $5 \%$ of cells in the VAT of lean individuals are composed of macrophages while this proportion rises to $50 \%$ in obese VAT $(23,24)$. Infiltrating macrophages in VAT of obese mice and humans surround dying adipocytes in an arrangement pathologically manifested as "crown-like structures" (CLS) (25). CLS are a morphological hallmark of obese VAT inflammation (Figure 1). Two major subtypes of macrophages are found in adipose tissue: "alternatively activated" M2 macrophages and "classically activated" M1 macrophages. The proportions of these cell populations in VAT are dependent on the tissue microenvironment. M2 macrophages maintain VAT homeostasis in lean individuals through the secretion of anti-inflammatory cytokines such as IL10 (26). During obesity, pro-inflammatory M1 polarized macrophages heavily outweigh M2 macrophages $(26,27)$. M1 macrophages secrete pro-inflammatory cytokines including TNFa, IL-1 $\beta$ and IL-6, some of which can directly alter insulin receptor signaling in adipocytes, leading to IR (26-28). In the CLS, M1 macrophages and adipocytes work closely to promote chronic inflammation and proliferation of other inflammatory immune cells (29).

The mechanisms leading to increased infiltration of macrophages into VAT during diet-induced obesity are not entirely clear. However, during obesity, adipocytes increase their expression of monocyte chemoattractant protein 1 (MCP-1) to recruit macrophages (30). More recently, IL-6 trans-signaling, involving the soluble form of the IL-6 receptor (sIL-6R) which binds IL-6 and together then bind gp130 expressing cells, has been shown to act as a chemotactic signal for bone marrow (BM)-derived monocyte migration into VAT (31). Once in the VAT, macrophage production of IL- $1 \beta$ binds IL-1 receptors on BM myeloid progenitors to stimulate monocyte and neutrophil proliferation (32). Further experimentation is required to test whether reducing adipose tissue macrophages or refining the balance of the M1 to M2 macrophage ratio in VAT is a viable treatment option for obesity-induced IR. Nonetheless, macrophages are a dominant immune cell type in mediating adipose tissue inflammation and IR.

\section{Neutrophils}

Neutrophils are among the first immune cells to respond at sites of inflammation and are known to fight infections through phagocytosis and the release of antimicrobial contents (33). Higher numbers of circulating activated neutrophils as measured by levels of myeloperoxidase (MPO), an antimicrobial protein, have been found in severely obese patients (34). Neutrophils are believed to be the first immune cell to infiltrate VAT during obesity and 


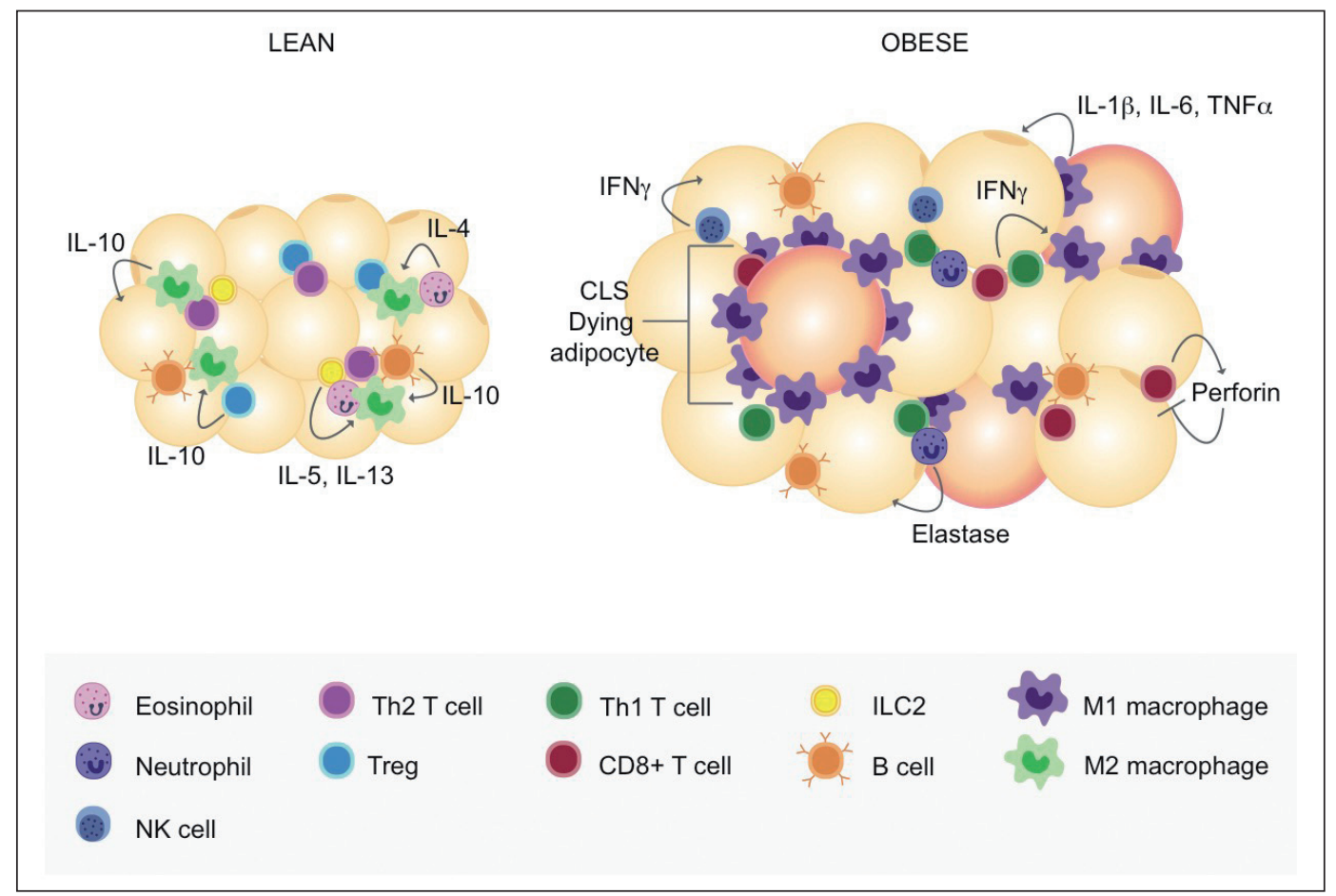

Figure 2: Changes of immune cell populations in adipose tissue during obesity. In lean VAT, regulatory B cells (Bregs), regulatory T cells (Tregs), Th2 T cells, eosinophils and type 2 innate lymphoid cells (ILC2s) maintain an anti-inflammatory environment through the production of IL-10, IL-4, IL-5, and IL-13. These anti-inflammatory cytokines promote anti-inflammatory M2 polarized macrophages in VAT. During obesity, there is an expansion of VAT, which leads to adipocyte hypertrophy, the secretion of adipokines and free fatty acids (FFA), the formation of crown-like structures (CLS) and adipocyte cell death. The immune cell profile in obese VAT is altered to a pro-inflammatory state. This includes increased elastase-secreting neutrophils and IFN $\gamma$-secreting CD8 T cells, Th1 T cells and NK cells. Inflammatory mediators promote pro-inflammatory M1 macrophage polarization and their release of IL-1 $\beta$, IL- 6 , and TNF- $\alpha$ cytokines. Perforin regulates $\mathrm{T}$ cell turnover and inflammatory activity of CD8 T cells in VAT.

initiate adipose tissue inflammation. In mice fed a high fat diet (HFD), an increased proportion of neutrophils were seen in VAT just after 3 days of feeding and maintained up to 12 weeks compared to normal chow diet (NCD)-fed mice $(35,36)$. Adipose tissue neutrophils in HFD-fed mice have increased secretion of serine proteases, such as elastase, which promote inflammation in a TLR4-dependent manner (35). Addition of elastase to hepatocytes in vitro decreased protein levels of important insulin signaling molecules including, IRS-1 and Akt, suggesting that elastase can also directly interfere with insulin signaling (35). Further investigation is needed to elucidate neutrophil function in initiating HFD-induced inflammation in VAT and if blocking the early arrival of these cells in this tissue can improve downstream IR.

\section{Eosinophils}

Eosinophils are innate immune cells involved in asthma and allergy, both of which are complicated by obesity $(37,38)$. Eosinophils are more numerous in lean VAT, and are major producers of IL-4 and IL-13, which help to promote M2 macrophage polarization to maintain a 'lean phenotype'(39). During a HFD feeding, mice deficient in eosinophils showed worsened IR and increased adipose tissue weight highlighting the importance of eosinophils in preventing obesity-related IR (39).

Cold temperatures and exercise can up-regulate meteorinlike hormone (Metrnl) expression in adipocytes and myocytes to stimulate eosinophils to trigger events that increase heat production and energy expenditure (40, 41). Eosinophils can activate M2 macrophages to convert white adipocytes into beige adipocytes in a process termed "browning", due to similar thermogenic properties of beige and brown fat. M2 macrophages induce tyrosine hydroxylase expression and catecholamine production to activate this browning process in adipocytes (40). Administration of IL-4, highly expressed by eosinophils, can improve dietinduced obesity. However, increasing eosinophil numbers may worsen asthma or allergies in obese individuals (37, 38). Thus, the implications of eosinophils in obesity, IR and its associated complications, such as asthma and allergy await further elucidation. 


\section{Type 2 Innate Lymphoid Cells (ILC2s)}

Innate lymphoid cells (ILCs), originally known to play a role in lymphoid tissue development, have recently been found to regulate inflammatory processes during obesity (42). Along with reduced numbers of eosinophils and M2 macrophages, obese humans and mice reportedly have decreased numbers of type 2 ILCs (ILC2s) in VAT (43). ILC2s produce IL-5 and IL-13 to promote eosinophil and M2 macrophage accumulation in VAT (44). The action of ILC2s is dependent on IL-33 stimulation to increase uncoupling protein 1 (UCP-1) expression in adipocytes, which increases caloric expenditure and promotes the biogenesis of beige adipose tissue $(43,45)$. Interestingly, ILC2s are able to increase UCP-1 expression in adipocytes directly through the production of methionine-enkephalin peptides (43). Thus, ILC2s may work independently or synergistically with eosinophils to drive the conversion of white to beige fat. Together with eosinophils, ILC2s may be exciting targets for white-beige adipose tissue conversion in future therapeutics for obesity-related IR.

\section{Mast Cells}

Mast cells are important inflammatory immune cells during allergy and inflammation but have not been well studied in adipose tissue and obesity. Similar to M1 macrophages and neutrophils, obese individuals have increased mast cells within VAT compared to lean individuals $(46,47)$. In a hyperglycemia model, high doses of glucose in vitro induce the activation of human mast cells to highly express proinflammatory cytokines including TNF $\alpha$, IL- $1 \beta$, and IL- 6 (48). Consistently, diet-induced obese mice deficient in mast cells are protected from weight gain and IR, possibly as a result of reduced VAT inflammation, as demonstrated by decreased amounts of IL-6, TNFa, IFN $\gamma$, MCP-1 and matrix metalloprotease-9 in VAT and serum (46). However, recent work challenges the notion of mast cell involvement in IR, as the phenotypes may be more dependent on the Kit mutation used in the mouse models, rather than a deficiency of mast cells themselves (49).

\section{Natural Killer (NK) Cells}

Natural killer (NK) cells are cytotoxic innate immune cells that have only been recently investigated in obesity and IR. NK cells are increased in the VAT of obese humans and mice and produce IFN $\gamma$, which promotes M1 macrophage polarization $(22,50,51)$. Induced ablation or genetic loss of NK cells has been found to improve IR and glucose tolerance $(22,52,53)$. HFD in mice induces adipocytes to increase expression of NK cell-activating receptor (NCR1) ligands to stimulate $\mathrm{NK}$ cells to proliferate and secrete IFN $\gamma$
(22). Thus, NK cells may be another important immune cell present in the inflammatory environment of obese VAT contributing to IR.

\section{ADAPTIVE IMMUNE CELLS}

\section{T Cells}

Numerous studies have supported a role for $\mathrm{T}$ cells in the inflammatory process of obese adipose tissue (54). During obesity, the composition of $\mathrm{T}$ cells in adipose tissue is altered favoring inflammatory subsets that promote IR. HFD feeding increases the amount of VAT resident T cells, which can be found dispersed in between adipocytes and within the CLS (21). T cells expressing either CD4 or CD8 likely contribute to inflammation in VAT through the release of pro-inflammatory cytokines, such as IFN $\gamma$ (55). Treatment of HFD-fed mice with an anti-CD3 T cell depleting antibody improved insulin sensitivity and limited adipose tissue inflammation (55). Furthermore, the majority of CD4 and CD8 T cells in VAT are effector memory $\mathrm{T}$ cells and express biased $\mathrm{T}$ cell receptor (TCR) repertoires, suggesting that the $\mathrm{T}$ cell responses may be antigen-specific (56). Although it is unclear whether these responses target specific self-reactive antigens or are merely the result of bystander immune activation, these findings raise the possibility of a potential autoimmune component to obesity-related IR (57).

IFN $\gamma$-producing CD8 $\mathrm{T}$ cells concentrate in the VAT of obese mice as early as 2 weeks after HFD feeding (58). In addition, subcutaneous adipose tissue display elevated CD8a expression in obese patients (58). Despite no changes in body weight, CD8 $\mathrm{T}$ cell deficient mice, or mice treated with anti-CD8 depleting antibody displayed improved glucose tolerance and insulin sensitivity, suggesting a pathogenic role for CD8 T cells in this process (58). Furthermore, depletion of CD8 T cells reduced the number of M1 macrophages in VAT, whereas adoptive transfer of CD8 T cells into CD8 null mice was sufficient to promote M1 macrophage infiltration in VAT, glucose intolerance and IR. A recent study has implicated a role for the cytolytic protein, perforin, which is produced by CD8 T cells and other immune cell types, in mediating $\mathrm{T}$ cell turnover in VAT which protects from IR (53).

CD4 T cells can mature into different subsets with distinct effector cytokine profiles including IFN $\gamma$-producing Th1 cells, IL-4-producing Th2 cells, IL-17-producing Th17 cells, and IL-10-producing regulatory T (Treg) cells. Th1 cells likely play an important role in VAT inflammation, as several studies have indicated that these cells accumulate in adipose tissue during obesity and outweigh Th2 cells 
(55). In humans, weight gain is correlated with increases in Th1 cells, and accordingly, VAT of obese humans has increased expression of the Th1 transcriptional regulator, T-bet $(55,59)$. IL-12p35 deficient mice, which have reduced Th1 cells, show improved insulin sensitivity during HFDfeeding. In addition, the dominant Th1 effector cytokine IFN $\gamma$ has been shown to directly impair insulin signaling in human adipocytes $(55,60)$. Interestingly, IFN $\gamma$ can also act on adipose tissue macrophages to enhance expression of MHC II, which promotes antigen presentation to Th1 cells resulting in their activation, proliferation and cytokine production (29).

Th17 cells are found in adipose tissue, but at much lower frequencies than Th1 cells (55). In humans, T cell IL-17 production seems to correlate with glucose intolerance, as measured by HBAlc in type 2 diabetics (61). IL-17 deficient HFD-fed mice display increased weight gain, but are more glucose tolerant and insulin sensitive, suggesting a pathogenic role for IL-17 in glucose homeostasis (62). Interestingly, much of the IL-17 produced in VAT is derived from $\gamma \delta$ T cells (62) and thus, more work is needed to better clarify roles for Th17 cells in adipose tissue inflammation.

In contrast to pro-inflammatory $\mathrm{T}$ cells, $\mathrm{T}$ regulatory cells (Tregs) counteract the development of chronic inflammation in VAT. Tregs express the transcription factor Foxp3 and are associated with potent anti-inflammatory capabilities. Tregs are highly enriched in lean adipose tissue and are believed to maintain insulin sensitivity by limiting inflammation and producing insulin-sensitizing cytokines, such as IL-10 (55). In lean adipose tissue, Tregs are also believed to promote the development of anti-inflammatory M2 macrophages (63). Interestingly, compared with other tissues, VAT Tregs express a unique gene signature with enhanced expression of PPAR $\gamma$, and IL-10 (64). A recent study determined that the accumulation of VAT Tregs is dependent on antigens presented in the context of MHC II molecules and the release of soluble mediators, including IL-33 (65). Over the course of HFD-feeding, Treg numbers decrease in VAT as they are diluted by increasing proinflammatory Th1 and CD8 $\mathrm{T}$ cells, which intensifies inflammation and adipose dysfunction $(55,64)$. Human studies measuring Foxp3 in adipose tissue during obesity also report a decrease in the number of Tregs (55). More recently, studies have determined that thiazolidinediones, which are well known PPAR $\gamma$ agonists used in the treatment of T2D, or gut-specific anti-inflammatory agents carry out a part of their insulin sensitizing effects by acting on Tregs to enhance their anti-inflammatory properties $(66,67)$.

\section{Natural Killer T (NKT) Cells}

NKT cells are innate-like $\mathrm{T}$ cells that share properties of both $\mathrm{T}$ cells and NK cells. They express the natural killer receptor 1.1 (NK1.1) and recognize CD1d associated lipid and glycolipid antigens (68). Based on their TCR diversity, they can be subdivided into variant (vNKT) or invariant (iNKT) cells. In general, VAT NKT cell numbers decrease during obesity in mice and humans (69-71). Whether NKT cells display pro- or anti-inflammatory effects in adipose tissue remains controversial. Studies have reported that the presence of NKT cells in adipose tissue improves glucose tolerance by promoting anti-inflammatory M2 macrophage polarization (69). Other studies have shown that iNKT cells play a role in limiting inflammation in adipose tissue by their release of IL-10 and IL-2, which helps sustain Treg activity (71). In contrast, transgenic mice that develop iNKT cells in excess exhibit dyslipidemia, enhanced M1 macrophages in VAT and impaired insulin sensitivity (72). Overall, the contribution of NKT cells in adipose tissue inflammation and IR remains inconclusive.

\section{B Cells}

Several studies have investigated the role of B cells and their different subsets in VAT inflammation. Upon HFDfeeding, pro-inflammatory B cells infiltrate adipose tissue prior to $\mathrm{T}$ cells, and promote the release of Th1-polarizing cytokines, such as IFN $\gamma$ and TNFa that modulate T cell and macrophage function $(73,74)$. Human B cells, but not monocytes, have been indicated to promote proinflammatory cytokine production by Th17 cells during obesity (74). HFD-fed B cell deficient mice are protected from IR, and transfer of IgG antibody from obese wild type mice into obese mice lacking $\mathrm{B}$ cells can worsen glucose intolerance and IR (73). Indeed, treatment of obese mice with depleting anti-CD20 antibody reverses IR and reduces VAT inflammation (73). One study reported that B cell inflammation during obesity might not be restricted to adipose tissue, as splenic B cells displayed a unique proinflammatory cytokine profile (74). Interestingly, more recent studies have identified the presence of $B$ regulatory cells and B-1a cells in adipose tissue and are more prominent during the lean state $(75,76)$. Adipose tissue Bregs (defined as IgM+IgD+CD22+), as well as B-1a cells, function to limit inflammation and protect from IR primarily through the release of anti-inflammatory cytokines such as IL-10. HFDfeeding reduces the frequency of these cells in VAT, and the transfer of B-1a cells into HFD-fed B cell deficient mice improves glucose tolerance and insulin sensitivity (76). 


\section{CONCLUDING REMARKS}

Low-grade chronic inflammation of VAT appears to be one driving link between obesity and IR. A great deal of complexity exists in the crosstalk between adipocytes and VAT-associated immune cells. Although many questions remain unanswered, it is likely that the balance between pro- and anti-inflammatory immune cells in VAT govern the outcome of metabolic disease (Figure 2). Lean VAT is concentrated by a variety of immune cells with potent antiinflammatory and insulin sensitizing capabilities. During excess food intake, hypertrophic and dying adipocytes lead to fibrotic changes and pro-inflammatory immune cell recruitment in VAT. Activated immune cells and their release of pro-inflammatory cytokines impair insulin signaling, leading to metabolic complications. Targeting VAT inflammation has shown success in the treatment of obesity-related IR in rodent models. Although further work is required, these findings have the potential to translate into new and innovative approaches in human patients to help manage this growing epidemic.

\section{ACKNOWLEDGMENTS}

This work was supported in part by CIHR grant 119414 (DW), and CDA grants OG-3-12-3844 (DW) and CS-512-3886 (DW). MG and HL received Canada Graduate Scholarships. XR received BBDC Fellowship in Diabetes Care (Eli Lilly Canada).

\section{CONFLICT OF INTEREST}

The authors have declared no conflict of interest.

\section{REFERENCES}

1. WHO. Global status report on noncommunicable diseases 2014 . Geneva: World Health Organization, 2014.

2. Mathers CD, Loncar D. Projections of global mortality and burden of disease from 2002 to 2030. PLoS Med. 2006;3:e442.

3. Khandekar MJ, Cohen P, Spiegelman BM. Molecular mechanisms of cancer development in obesity. Nat Rev Cancer. 2011;11:88695.

4. Masuoka HC, Chalasani N. Nonalcoholic fatty liver disease: an emerging threat to obese and diabetic individuals. Ann N Y Acad Sci. 2013;1281:106-22.

5. Rask-Madsen C, Kahn CR. Tissue-specific insulin signaling, metabolic syndrome, and cardiovascular disease. Arterioscler Thromb Vasc Biol. 2012;32:2052-9.

6. Villareal DT, Apovian CM, Kushner RF, Klein S; American Society for Nutrition; NAASO, The Obesity Society. Obesity in older adults: Technical review and position statement of the American Society for Nutrition and NAASO, The Obesity Society. Obes Res. 2005;13(11):1849-63
7. Wronska A, Kmiec Z. Structural and biochemical characteristics of various white adipose tissue depots. Acta Physiol (Oxf). 2012;205:194-208.

8. Divoux A, Clément K. Architecture and the extracellular matrix: The still unappreciated components of the adipose tissue. Obes Rev. 2011;12:e494-503

9. Arner P. Human fat cell lipolysis: Biochemistry, regulation and clinical role. Best Pract Res Clin Endocrinol Metab. 2005;19:47182.

10. Spalding KL, Arner E, Westermark PO, Bernard S, Buchholz BA, Bergmann O, Blomqvist L, Hoffstedt J, Näslund E, Britton T, Concha H, Hassan M, Rydén M, Frisén J, Arner P. Dynamics of fat cell turnover in humans. Nature. 2008;453(7196):783-7.

11. Skurk T, Alberti-Huber C, Herder C, Hauner H. Relationship between adipocyte size and adipokine expression and secretion. J Clin Endocrinol Metab. 2007;92:1023-33.

12. Cao Y. Angiogenesis modulates adipogenesis and obesity. J Clin Invest. 2007;117:2362-8.

13. Cao Y. Adipose tissue angiogenesis as a therapeutic target for obesity and metabolic diseases. Nat Rev Drug Discov. 2010;9:10715.

14. Giordano A, Murano I, Mondini E, Perugini J, Smorlesi A, Severi I, Barazzoni R, Scherer PE, Cinti S. Obese adipocytes show ultrastructural features of stressed cells and die of pyroptosis. J Lipid Res. 2013;54:2423-36

15. Hosogai N, Fukuhara A, Oshima K, Miyata Y, Tanaka S, Segawa K, Furukawa S, Tochino Y, Komuro R, Matsuda M, Shimomura I. Adipose tissue hypoxia in obesity and its impact on adipocytokine dysregulation. Diabetes. 2007;56:901-11.

16. Pasarica M, Gowronska-Kozak B, Burk D, Remedios I, Hymel D, Gimble J, Ravussin E, Bray GA, Smith SR. Adipose tissue collagen VI in obesity. J Clin Endocrinol Metab. 2009;94:5155-62.

17. Mariman EC, Wang P. Adipocyte extracellular matrix composition, dynamics and role in obesity. Cell Mol Life Sci. 2010;67:1277-92.

18. Szendroedi J, Roden M. Ectopic lipids and organ function. Curr Opin Lipidol. 2009;20:50-6.

19. Sell H, Eckel J. Adipose tissue inflammation: Novel insight into the role of macrophages and lymphocytes. Curr Opin Clin Nutr Metab Care. 2010;13:366-70.

20. Osborn O, Olefsky JM. The cellular and signaling networks linking the immune system and metabolism in disease. Nat Med. 2012;18:363-74.

21. Olefsky JM, Glass CK. Macrophages, inflammation, and insulin resistance. Annu Rev Physiol. 2010;72:219-46.

22. Wensveen FM, Jelenčić V, Valentić S, Šestan M, Wensveen TT, Theurich S, Glasner A, Mendrila D, Štimac D, Wunderlich FT, Brüning JC, Mandelboim O, Polić B. NK cells link obesityinduced adipose stress to inflammation and insulin resistance. Nat Immunol. 2015; 16:376-85.

23. Weisberg SP, McCann D, Desai M, Rosenbaum M, Leibel RL, Ferrante AW Jr. Obesity is associated with macrophage accumulation in adipose tissue. J Clin Invest. 2003;112:1796-808. 
24. Xu H, Barnes GT, Yang Q, Tan G, Yang D, Chou CJ, Sole J, Nichols A, Ross JS, Tartaglia LA, Chen H. Chronic inflammation in fat plays a crucial role in the development of obesity-related insulin resistance. J Clin Invest. 2003;112:1821-30.

25. Cinti S, Mitchell G, Barbatelli G, Murano I, Ceresi E, Faloia E, Wang S, Fortier M, Greenberg AS, Obin MS. Adipocyte death defines macrophage localization and function in adipose tissue of obese mice and humans. J Lipid Res. 2005;46:2347-55.

26. Lumeng CN, Bodzin JL, Saltiel AR. Obesity induces a phenotypic switch in adipose tissue macrophage polarization. J Clin Invest. 2007;117:175-84.

27. Lumeng CN, Deyoung SM, Bodzin JL, Saltiel AR. Increased inflammatory properties of adipose tissue macrophages recruited during diet-induced obesity. Diabetes. 2007;56:16-23.

28. Hotamisligil GS, Murray DL, Choy LN, Spiegelman BM. Tumor necrosis factor alpha inhibits signaling from the insulin receptor. Proc Natl Acad Sci U S A. 1994;91:4854-8.

29. Morris DL, Cho KW, Delproposto JL, Oatmen KE, Geletka LM, Martinez-Santibanez G, Singer K, Lumeng CN. Adipose tissue macrophages function as antigen-presenting cells and regulate adipose tissue CD4+ T cells in mice. Diabetes. 2013;62:2762-72.

30. Kanda H, Tateya S, Tamori Y, Kotani K, Hiasa K, Kitazawa R, Kitazawa S, Miyachi H, Maeda S, Egashira K, Kasuga M. MCP1 contributes to macrophage infiltration into adipose tissue, insulin resistance, and hepatic steatosis in obesity. J Clin Invest. 2006;116:1494-505.

31. Kraakman MJ, Kammoun HL, Allen TL, Deswaerte V, Henstridge DC, Estevez E, Matthews VB, Neill B, White DA, Murphy AJ, Peijs L, Yang C, Risis S, Bruce CR, Du XJ, Bobik A, Lee-Young RS, Kingwell BA, Vasanthakumar A, Shi W, Kallies A, Lancaster GI, Rose-John S, Febbraio MA. Blocking IL-6 trans-signaling prevents high-fat diet-induced adipose tissue macrophage recruitment but does not improve insulin resistance. Cell Metab. 2015;21:403-16.

32. Nagareddy PR, Kraakman M, Masters SL, Stirzaker RA, Gorman DJ, Grant RW, Dragoljevic D, Hong ES, Abdel-Latif A, Smyth SS, Choi SH, Korner J, Bornfeldt KE, Fisher EA, Dixit VD, Tall AR, Goldberg IJ, Murphy AJ. Adipose tissue macrophages promote myelopoiesis and monocytosis in obesity. Cell Metab. 2014;19:821-35.

33. Brinkmann V, Reichard U, Goosmann C, Fauler B, Uhlemann Y, Weiss DS, Weinrauch Y, Zychlinsky A. Neutrophil extracellular traps kill bacteria. Science. 2004;303(5663):1532-5.

34. Nijhuis J, Rensen SS, Slaats Y, van Dielen FM, Buurman WA, Greve JW. Neutrophil activation in morbid obesity, chronic activation of acute inflammation. Obesity (Silver Spring). 2009;17:2014-8.

35. Talukdar S, Oh da Y, Bandyopadhyay G, Li D, Xu J, McNelis J, Lu M, Li P, Yan Q, Zhu Y, Ofrecio J, Lin M, Brenner MB, Olefsky JM. Neutrophils mediate insulin resistance in mice fed a high-fat diet through secreted elastase. Nat Med. 2012;18:1407-12.

36. Elgazar-Carmon V, Rudich A, Hadad N, Levy R. Neutrophils transiently infiltrate intra-abdominal fat early in the course of high-fat feeding. J Lipid Res. 2008;49:1894-903.
37. Grotta MB, Squebola-Cola DM, Toro AA, Ribeiro MA, Mazon SB, Ribeiro JD, Antunes E. Obesity increases eosinophil activity in asthmatic children and adolescents. BMC Pulm Med. 2013 $18 ; 13: 39$.

38. van Huisstede A, Cabezas MC, Birnie E, van de Geijn GJ, Rudolphus A, Mannaerts G, Njo TL, Hiemstra PS, Braunstahl GJ. Systemic inflammation and lung function impairment in morbidly obese subjects with the metabolic syndrome. J Obes. 2013;2013:131349.

39. Wu D, Molofsky AB, Liang HE, Ricardo-Gonzalez RR, Jouihan HA, Bando JK, Chawla A, Locksley RM. Eosinophils sustain adipose alternatively activated macrophages associated with glucose homeostasis. Science. 2011;332(6026):243-7.

40. Qiu Y, Nguyen KD, Odegaard JI, Cui X, Tian X, Locksley RM, Palmiter RD, Chawla A. Eosinophils and type 2 cytokine signaling in macrophages orchestrate development of functional beige fat. Cell. 2014;157:1292-308.

41. Rao RR, Long JZ, White JP, Svensson KJ, Lou J, Lokurkar I, Jedrychowski MP, Ruas JL, Wrann CD, Lo JC, Camera DM, Lachey J, Gygi S, Seehra J, Hawley JA, Spiegelman BM. Meteorinlike is a hormone that regulates immune-adipose interactions to increase beige fat thermogenesis. Cell. 2014;157:1279-91.

42. McKenzie AN, Spits H2, Eberl G3. Innate lymphoid cells in inflammation and immunity. Immunity. 2014;41:366-74.

43. Brestoff JR, Kim BS, Saenz SA, Stine RR, Monticelli LA, Sonnenberg GF, Thome JJ, Farber DL, Lutfy K, Seale P, Artis D. Group 2 innate lymphoid cells promote beiging of white adipose tissue and limit obesity. Nature. 2015;519(7542):242-6.

44. Molofsky AB, Nussbaum JC, Liang HE, Van Dyken SJ, Cheng LE, Mohapatra A, Chawla A, Locksley RM. Innate lymphoid type 2 cells sustain visceral adipose tissue eosinophils and alternatively activated macrophages. J Exp Med. 2013;210:535-49.

45. Lee MW, Odegaard JI, Mukundan L, Qiu Y, Molofsky AB, Nussbaum JC, Yun K, Locksley RM, Chawla A. Activated type 2 innate lymphoid cells regulate beige fat biogenesis. Cell. 2015;160:74-87.

46. Liu J, Divoux A, Sun J, Zhang J, Clément K, Glickman JN, Sukhova GK, Wolters PJ, Du J, Gorgun CZ, Doria A, Libby P, Blumberg RS, Kahn BB, Hotamisligil GS, Shi GP. Genetic deficiency and pharmacological stabilization of mast cells reduce diet-induced obesity and diabetes in mice. Nat Med. 2009;15:940-5

47. Divoux A, Moutel S, Poitou C, Lacasa D, Veyrie N, Aissat A, Arock M, Guerre-Millo M, Clément K. Mast cells in human adipose tissue: Link with morbid obesity, inflammatory status, and diabetes. J Clin Endocrinol Metab. 2012;97:E1677-85.

48. Nagai K, Fukushima T, Oike H, Kobori M. High glucose increases the expression of proinflammatory cytokines and secretion of TNFalpha and beta-hexosaminidase in human mast cells. Eur J Pharmacol. 2012;687:39-45.

49. Gutierrez DA, Muralidhar S, Feyerabend TB, Herzig S, Rodewald HR. Hematopoietic kit deficiency, rather than lack of mast cells, protects mice from obesity and insulin resistance. Cell Metab. 2015;21:678-91. 
50. O’Rourke RW, Metcalf MD, White AE, Madala A, Winters BR, Maizlin II, Jobe BA, Roberts CT Jr, Slifka MK, Marks DL. Depotspecific differences in inflammatory mediators and a role for NK cells and IFN-gamma in inflammation in human adipose tissue. Int J Obes (Lond). 2009;33:978-90.

51. O’Rourke RW, Gaston GD, Meyer KA, White AE, Marks DL. Adipose tissue NK cells manifest an activated phenotype in human obesity. Metabolism. 2013 Nov;62(11):1557-61.

52. O'Rourke RW, Meyer KA, Neeley CK, Gaston GD, Sekhri P, Szumowski M, Zamarron B, Lumeng CN, Marks DL. Systemic NK cell ablation attenuates intra-abdominal adipose tissue macrophage infiltration in murine obesity. Obesity (Silver Spring). 2014;22:2109-14.

53. Revelo XS, Tsai S, Lei H, Luck H, Ghazarian M, Tsui H, Shi SY, Schroer S, Luk CT, Lin GH, Mak TW, Woo M, Winer S, Winer DA. Perforin is a novel immune regulator of obesity-related insulin resistance. Diabetes. 2015;64:90-103.

54. Winer S, Winer DA. The adaptive immune system as a fundamental regulator of adipose tissue inflammation and insulin resistance. Immunol Cell Biol. 2012;90:755-62.

55. Winer S, Chan Y, Paltser G, Truong D, Tsui H, Bahrami J, Dorfman R, Wang Y, Zielenski J, Mastronardi F, Maezawa Y, Drucker DJ, Engleman E, Winer D, Dosch HM. Normalization of obesity-associated insulin resistance through immunotherapy. Nat Med. 2009;15:921-9.

56. Yang H, Youm YH, Vandanmagsar B, Ravussin A, Gimble JM, Greenway F, Stephens JM, Mynatt RL, Dixit VD. Obesity increases the production of proinflammatory mediators from adipose tissue $\mathrm{T}$ cells and compromises TCR repertoire diversity: implications for systemic inflammation and insulin resistance.J Immunol. 2010;185:1836-45.

57. Tsai S, Clemente-Casares X, Revelo XS, Winer S, Winer DA. Are obesity-related insulin resistance and type 2 diabetes autoimmune diseases? Diabetes. 2015;64:1886-97.

58. Nishimura S, Manabe I, Nagasaki M, Eto K, Yamashita H, Ohsugi M, Otsu M, Hara K, Ueki K, Sugiura S, Yoshimura K, Kadowaki T, Nagai R. CD8+ effector T cells contribute to macrophage recruitment and adipose tissue inflammation in obesity. Nat Med. 2009;15:914-20.

59. Strissel KJ, DeFuria J, Shaul ME, Bennett G, Greenberg AS, Obin MS. T-cell recruitment and Th1 polarization in adipose tissue during diet-induced obesity in C57BL/6 mice. Obesity (Silver Spring). 2010;18:1918-25.

60. McGillicuddy FC, Chiquoine EH, Hinkle CC, Kim RJ, Shah R, Roche HM, Smyth EM, Reilly MP. Interferon gamma attenuates insulin signaling, lipid storage, and differentiation in human adipocytes via activation of the JAK/STAT pathway. J Biol Chem. 2009;284:31936-44.

61. Jagannathan-Bogdan $M$, McDonnell ME, Shin H, Rehman Q, Hasturk H, Apovian CM, Nikolajczyk BS. Elevated proinflammatory cytokine production by a skewed $\mathrm{T}$ cell compartment requires monocytes and promotes inflammation in type 2 diabetes. J Immunol. 2011;186:1162-72.
62. Zúñiga LA, Shen WJ, Joyce-Shaikh B, Pyatnova EA, Richards AG, Thom C, Andrade SM, Cua DJ, Kraemer FB, Butcher EC. IL-17 regulates adipogenesis, glucose homeostasis, and obesity. J Immunol. 2010;185:6947-59.

63. Tiemessen MM, Jagger AL, Evans HG, van Herwijnen MJ, John S, Taams LS. CD4+CD25+Foxp3+ regulatory $\mathrm{T}$ cells induce alternative activation of human monocytes/macrophages. Proc Natl Acad Sci U S A. 2007;104:19446-51.

64. Cipolletta D, Kolodin D, Benoist C, Mathis D. Tissular T(regs): A unique population of adipose-tissue-resident Foxp3+CD4+ $\mathrm{T}$ cells that impacts organismal metabolism. Semin Immunol. 2011;23:431-7.

65. Kolodin D, van Panhuys N, Li C, Magnuson AM, Cipolletta D, Miller CM, Wagers A, Germain RN, Benoist C, Mathis D. Antigen- and cytokine-driven accumulation of regulatory $\mathrm{T}$ cells in visceral adipose tissue of lean mice. Cell Metab. 2015;21:54357.

66. Cipolletta D, Feuerer M, Li A, Kamei N, Lee J, Shoelson SE, Benoist C, Mathis D. PPAR-gamma is a major driver of the accumulation and phenotype of adipose tissue Treg cells. Nature. 2012;486:549-53.

67. Luck H, Tsai S, Chung J, Clemente-Casares X, Ghazarian M, Revelo XS, Lei H, Luk CT, Shi SY, Surendra A, Copeland JK, Ahn J, Prescott D, Rasmussen BA, Chng MH, Engleman EG, Girardin SE, Lam TK, Croitoru K, Dunn S, Philpott DJ, Guttman DS, Woo M, Winer S, Winer DA. Regulation of obesity-related insulin resistance with gut anti-inflammatory agents. Cell Metab. 2015;21:527-42.

68. Rossjohn J, Pellicci DG, Patel O, Gapin L, Godfrey DI. Recognition of CD1d-restricted antigens by natural killer T cells. Nat Rev Immunol. 2012;12:845-57.

69. Ji Y, Sun S, Xu A, Bhargava P, Yang L, Lam KS, Gao B, Lee CH, Kersten S, Qi L. Activation of natural killer T cells promotes M2 Macrophage polarization in adipose tissue and improves systemic glucose tolerance via interleukin-4 (IL-4)/STAT6 protein signaling axis in obesity. J Biol Chem. 2012;287:13561-71.

70. Schipper HS, Rakhshandehroo M, van de Graaf SF, Venken K, Koppen A, Stienstra R, Prop S, Meerding J, Hamers N, Besra G, Boon L, Nieuwenhuis EE, Elewaut D, Prakken B, Kersten S, Boes M, Kalkhoven E. Natural killer T cells in adipose tissue prevent insulin resistance. J Clin Invest. 2012;122:3343-54.

71. Lynch L, Nowak M, Varghese B, Clark J, Hogan AE, Toxavidis V, Balk SP, O'Shea D, O'Farrelly C, Exley MA. Adipose tissue invariant NKT cells protect against diet-induced obesity and metabolic disorder through regulatory cytokine production. Immunity. 2012;37:574-87

72. Subramanian S, Turner MS, Ding Y, Goodspeed L, Wang S, Buckner JH, O’Brien K, Getz GS, Reardon CA, Chait A. Increased levels of invariant natural killer T lymphocytes worsen metabolic abnormalities and atherosclerosis in obese mice. J Lipid Res. 2013;54:2831-41. 
73. Winer DA, Winer S, Shen L, Wadia PP, Yantha J, Paltser G, Tsui $\mathrm{H}$, Wu P, Davidson MG, Alonso MN, Leong HX, Glassford A, Caimol M, Kenkel JA, Tedder TF, McLaughlin T, Miklos DB, Dosch HM, Engleman EG. B cells promote insulin resistance through modulation of T cells and production of pathogenic IgG antibodies. Nat Med. 2011;17:610-7.

74. DeFuria J, Belkina AC, Jagannathan-Bogdan M, Snyder-Cappione J, Carr JD, Nersesova YR, Markham D, Strissel KJ, Watkins AA, Zhu M, Allen J, Bouchard J, Toraldo G, Jasuja R, Obin MS, McDonnell ME, Apovian C, Denis GV, Nikolajczyk BS. B cells promote inflammation in obesity and type 2 diabetes through regulation of T-cell function and an inflammatory cytokine profile. Proc Natl Acad Sci U S A. 2013;110:5133-8.
75. Nishimura S, Manabe I, Takaki S, Nagasaki M, Otsu M, Yamashita H, Sugita J, Yoshimura K, Eto K, Komuro I, Kadowaki T, Nagai $\mathrm{R}$. Adipose natural regulatory $\mathrm{B}$ cells negatively control adipose tissue inflammation. Cell Metab. 2013:S1550-4131(13)00386-0.

76. Shen L, Chng MH, Alonso MN, Yuan R, Winer DA, Engleman EG. B-1a lymphocytes attenuate insulin resistance. Diabetes. 2015;64:593-603. 